\title{
New species of Sloanea (Elaeocarpaceae) from the Brazilian Cerrado
}

\author{
New species of Sloanea (Elaeocarpaceae) from the Brazilian Cerrado
}

Daniela Sampaio ${ }^{1,2}$ \& Vinicius Castro Souza ${ }^{3}$

\begin{abstract}
Sloanea petalata D. Sampaio \& V.C. Souza is an endemic species known only from Mogi-Guaçu municipality, in the Cerrado of São Paulo state, Brazil. This new species shares some features with Sloanea garckeana K. Schum., differing mainly in the presence of petals, an uncommon characteristic among Neotropical species of this genus. Description of Sloanea petalata, as well as illustration, diagnosis, and comments on distribution are provided in this paper.

Key words: Brazilian savanna, conservation status, taxonomy.

\section{Resumo}

Sloanea petalata D. Sampaio \& V.C. Souza é uma espécie endêmica do Cerrado do município de Mogi Guaçu, estado de São Paulo, Brasil. Essa nova espécie é semelhante a Sloanea garckeana K. Schum., da qual pode ser diferenciada principalmente pela presença das pétalas, característica incomum nas espécies neotropicais do gênero. A descrição de Sloanea petalata, bem como ilustrações, diagnose e comentários sobre a distribuição geográfica são apresentados neste trabalho.
\end{abstract}

Palavras-chave: Cerrado, status de conservação, taxonomia.

\section{Introduction}

The genus Sloanea is comprised by at least 150 species occurring in the Old and New World (Mabberley 2008). About 40 species are found in Brazil, which are distributed in various types of vegetation, and they are usually located near water-courses and in preserved environments (Smith 1954; Sampaio 2009). The Amazon Rainforest, the Atlantic Forest, and Cerrado Vegetation are the biomes with the highest diversity of Sloanea species in Brazil. In the Brazilian extraAmazonian region, the Sloanea species are assigned to both Quadrisepala and Sloanea subgenera, according to the classification proposed by Smith (1954) based on the position of the calyx in the flower bud. Moreover, the species of the New World had been characterized as monochlamydeous, but two dichlamydeous species, Sloanea jamaicensis Hook. and Sloanea petalata - here presented - have been registered in the Neotropics region. Due to the presence of petals and sepals covering the reproductive organs on the flower bud near anthesis, $S$. petalata was included in the subgenus Quadrisepala.

Sloanea petalata D. Sampaio \& V.C. Souza, sp. nov. Type: BRAZIL. SÃO PAULO: Rodovia CampinasMogi Mirim, Auto Posto Varanda, 12.XII.1980, $H$. Leitão-Filho 12087 (holotype UEC!; isotype RB!).

Fig. 1

Affinis Sloanea garckeana K. Schum., inflorescentia -3 et ovario longe velutino sed praesentia petalorum differt.

Trees 10-15 m tall. Leaves alternate; stipules early deciduous, 6-9 × ca. $1 \mathrm{~mm}$, filiform, pubescent; petioles $0.9-1.3 \mathrm{~cm}$ long, pubescent to tomentose on the upper portion; leaf blade obovate, 7-13 × 3.5-6 cm, base acute, apex acute, margins entire or serrate on the first upper third of blade, glabrous on both surfaces, except for on the veins;

\footnotetext{
'Author for correspondence: Universidade Presbiteriana Mackenzie, Centro de Ciências Biológicas e da Saúde, R. Consolação 896, 01302-907, São Paulo, SP, Brazil. sampaio.dani@gmail.com

${ }^{2}$ Pós-graduanda do Curso de Biologia Vegetal, Universidade Estadual de Campinas - UNICAMP, CP 6109, 13083-970, Campinas, SP, Brazil.

${ }^{3}$ Universidade de São Paulo (ESALQ-USP), Escola Superior de Agricultura ‘Luiz de Queiroz’, Depto. Ciências Biológicas, Av. Pádua Dias 11, 13018-900, C.P. 19, Piracicaba, SP, Brazil.
} 


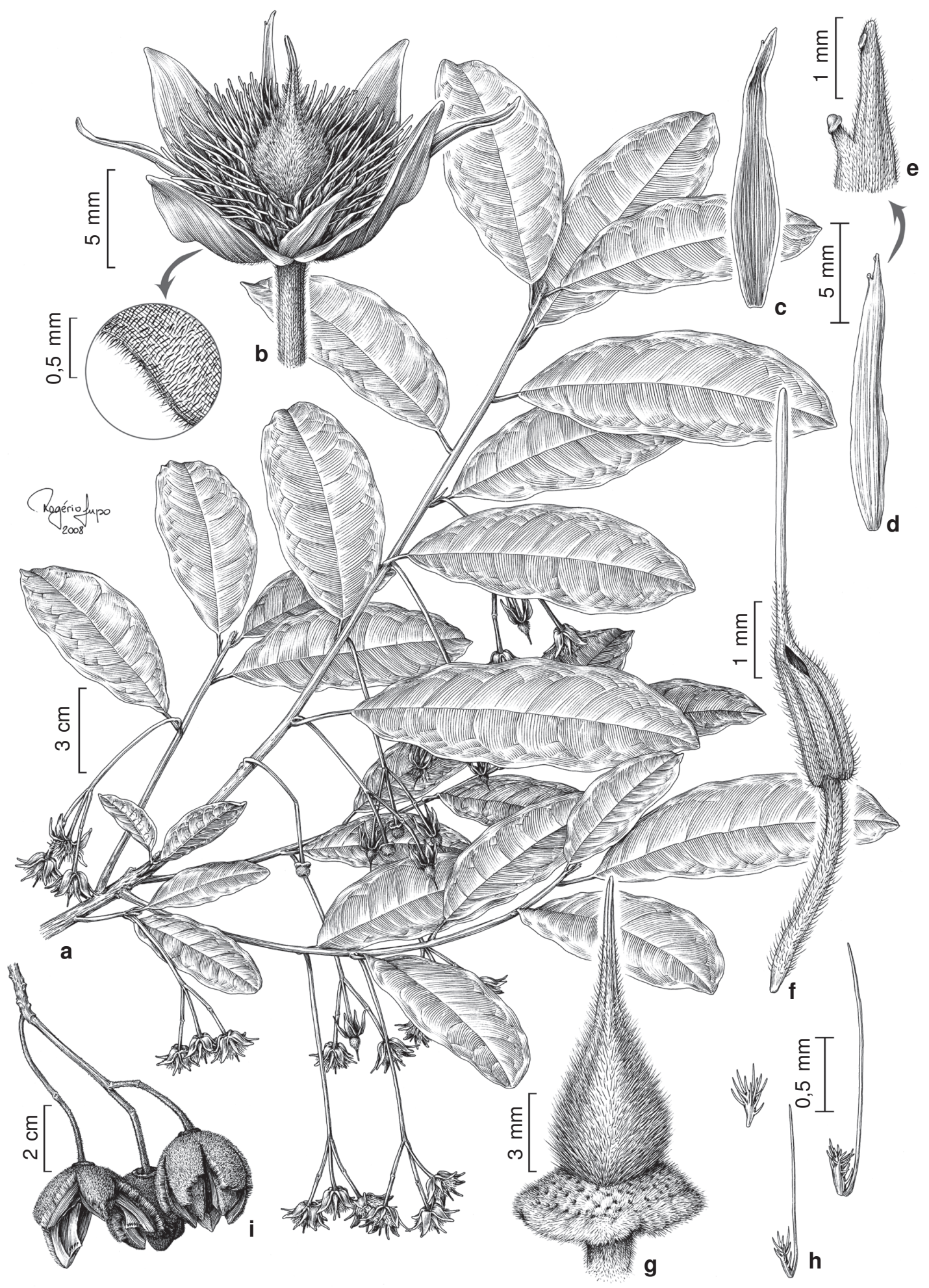

Figure 1 - Sloanea petalata - a. flowering stem; b. opened flower and detail of the indument on the inner surface of the sepal; c. inner surface of the petal; d. outside surface of the petal; e. detail of the apex; f. detail of the stamen; g. detail of the ovary; h. detail of the branched trichomes from the ovary; i. mature fruits (a-f Leitão-Filho 12087; g-h Gibbs \& Leitão-Filho 3553; i. collection of Rossi 2119). 
venation brochidodromous on the first third of the lower blade, semicraspedodromous on the upper portion, midrib grooved on adaxial surface, prominent on abaxial surface; domatia absent. Inflorescence axillary; triad type; peduncle 1.5-4.5 $\mathrm{cm}$ long, striate, non-lenticellate, cylindrical, pubescent to tomentose; bracts and bracteoles early deciduous, not seen; pedicels $0.9-2.5 \mathrm{~cm}$ long, striate, pubescent to tomentose. Flowers with 4sepals, uniseriate, entire, 11-15 × 3-4 mm, ovate, apex acuminate, margins revolute, pubescent on both surfaces, more densely on a line on the inner surface; petals 4 , uniseriate, entire, $7-13 \times \mathrm{ca} .1 \mathrm{~mm}$, lanceolate, apex acuminate, margins revolute, pubescent on both surfaces, petals covering the reproductive organs on the floral buds near anthesis; filaments 2-3 mm long, hirsute; anthers ca. $2 \mathrm{~mm}$ long, elliptical, pubescent; connective prolonged into an aristate awn, 3-4 mm long, glabrous; ovary ca. $6 \mathrm{~mm}$ long, globose, velutinous, with branched trichomes, sessile; style ca. $5 \mathrm{~mm}$ long, straight or twisted, apex entire, velutinous on the basal portion, glabrous on the apical portion; floral receptacle densely pubescent. Fruits orbicular, $2-3 \times 0.7-1.3 \mathrm{~cm}$, valves 4 or 5 , pubescent, externally covered by pubescent bristles, the bristles 2-4 mm long. Seeds not seen.

Examined material: BRASIL. SÃO PAULO: Mogi Guaçu, Estação Experimental de Mogi Guaçu (Fazenda Campininha), 26.XI.1973, fl., P.E. Gibbs \& H. LeitãoFilho 3553. (MBM 49255, TE 1727, UEC 4105); Estrada Campinas-Mogi Mirim, Super Posto Varanda (km 156), 14.VII.2000, fr., L. Rossi \& O.T. Oyakawa 2119 (SP); Posto Varanda, 12.XII.1980, F. de Barros 592 (SP 167115); lateral do Auto Posto Varanda, 13.VIII.2007, fr., D. Sampaio 1801 (ESA).

Sloanea petalata is known only from the type locality, the city of Mogi Guaçu, state of São Paulo, an area with predominance of Cerrado Vegetation. This species is one of the few of its genus that occurs in drier habitats and apparently away from water-courses. Typically, $S$. petalata blooms from November to December.
The epithet is referred due to the presence of petals, an uncommon feature in the New World species.

Besides the endemic distribution restricted to the region of Mogi Guaçu city just few individuals of this species were found in disturbed areas. Due to that, $S$. petalata was classified as Critically Endangered (CR) by the criteria of IUCN (2001), following the criteria B1abIII - extent of occurrence estimated to be less than $100 \mathrm{~km}^{2}$ and estimates indicating only a single location and continuing decline in quality of habitat.

Sloanea petalata shares some characteristics with $S$. garckeana K. Schum. such as inflorescence type (a triad), the connective prolonged into an aristate awn, and the velutinous indument that covers the ovary. However, it can be distinguished from $S$. garckeana in having petals and longer filaments ( $3 \mathrm{~mm}$ long in $S$. petalata vs. $1-2 \mathrm{~mm}$ long in $S$. garckeana) and ovary (ca. $6 \mathrm{~mm}$ long in $S$. petalata vs. 3-4 mm long in S. garckeana).

\section{Acknowledgments}

We acknowledge FAPESP for the financial support to carry out this research; Lúcia Rossi (SP) and Marcus Nadruz Coelho (RB) for their suggestions during the research, and Isabela Mascia Silveira for the English revision of the mansucript.

\section{References}

IUNC. 2001. IUNC Red List Categories and Criteria: Version 3.1. IUNC Species Commission. IUNC, Gland and Cambridge. 33p.

Mabberley, D.J. 2008. The plant book: A portable dictionary of the vascular plants. 3 ed. Cambridge University Press, Cambridge. 1021p.

Sampaio, D. 2009. Revisão taxonômica das espécies neotropicais extra-amazônicas de Sloanea L. (Elaeocarpaceae) na América do Sul. 168p. Tese de Doutorado. Universidade Estadual de Campinas, Campinas.

Smith, C.E. 1954. The new world species of Sloanea (Elaeocarpaceae). Contribution Gray Herbarium of Harvard University 175: 1-144. 